\title{
Article
}

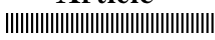

\section{Observation of the Movement of the Precipitation by Using Tritium Tracer}

\author{
Yurong JiAO, Sayuri IsHIDA, Kayoko TAKADA*, \\ Hiroshi IMAIZUMI* Naoki KANO* and Masaaki SAITO** \\ Graduate School of Science and Technology, Niigata University \\ * Department of Chemistry and Chemical Engineering, Faculty of Engineering, Niigata University \\ 8050 Ikarashi 2-Nocho, Nishi-ku, Niigata-shi, Niigata Pref. 950-2181, Japan \\ ** Tokyo Metropolitan Industrial Technology Research Institute Komazawa Lab. \\ 2-11-1 Fukasawa, Setagaya-ku, Tokyo 158-0081, Japan
}

Received February 25, 2011

\begin{abstract}
Tracer techniques have proven to be one of the most powerful tools to characterize the movement of air mass and pollutant transport in hydrological systems. In order to clarify the behavior of low-level tritium in the rain water, we have employed the measuring method of tritium applying a distillation process and an electrolytic enrichment process. The activity of tritium (T specific activity) in the obtained water was measured by liquid scintillation counter. This procedure was applied to bulk precipitation, imitative ground infiltrated precipitation and short term precipitation collected in Niigata City. Moreover, we investigated the concentrations of cations $\left(\mathrm{Na}^{+}, \mathrm{K}^{+}, \mathrm{Ca}^{2+}\right.$, and $\left.\mathrm{Mg}^{2+}\right)$ in the precipitation to associate with air mass transport patterns arriving at the place. From the above mentioned, next matters have been clarified : (1) T specific activity in precipitation was found to have a strong dependence on location and season. (2) The chemical components in precipitation during typhoon have notable character of marine air mass. (3) Associated ions in monthly precipitation showed seasonal variation, in fact, the seasonal variation of $\mathrm{Ca}^{2+}$ and tritium were very similar. (4) Backward trajectory analysis method is useful for the analysis of the behavior of T specific activity and several ions in short-term precipitation.
\end{abstract}

Key Words : precipitation, tritium tracer, air mass, backward trajectory analysis, Niigata City

\section{Introduction}

Tritium $\left({ }^{3} \mathrm{H}\right.$ or $\left.\mathrm{T}\right)$, a radioactive isotope of hydrogen, is one of the most important transient tracers used in hydrological research. $\mathrm{T}$ is a pure beta emitter $\left(\mathrm{E}_{\max }=18.6 \mathrm{keV}\right)$ with the half-life of 12.32 years ${ }^{1)}$. $T$ is also found in the natural world, and can be produced by human activities (e.g., nuclear power plant). The natural origin is associated with the interaction of cosmic rays with the atmosphere. However, the environmental levels of this radionuclide were enhanced by the atmospheric nuclear test conducted from 1945 to 1963 . Since the atmospheric nuclear weapon tests were stopped (1963), the released activity of $\mathrm{T}$ in the atmosphere ${ }^{2), 3)}$ has decayed with its half-life. Nowadays, the level of $\mathrm{T}$ in the atmosphere is similar to its natural origin before the nuclear tests. At present, HTO activities in nature are about $0.5-1 \mathrm{~Bq} \cdot \mathrm{dm}^{-3}$ in precipitation, less than 10 $\mathrm{Bq} \cdot \mathrm{dm}^{-3}$ in rivers, $1-10 \mathrm{~Bq} \cdot \mathrm{dm}^{-3}$ in aquifers, less than $0.3 \mathrm{~Bq} \cdot \mathrm{dm}^{-3}$ in seawater, $2-4 \mathrm{~Bq}$. $\mathrm{dm}^{-3}$ in the ice of the poles ${ }^{4)}$.

$\mathrm{T}$ specific activity in precipitation depends on latitude, sea, distance from artificial sources, 
and thermonuclear test zones. In hydrology, T gives the movement of useful hydrological and meteorological informations that can be obtained by measuring the natural $\mathrm{T}$ specific activity in precipitation, surface water, and groundwater $^{5), 6}$.

The purpose of this work was (1) to clarify the movement and origin of air mass (bringing out precipitation) by applying the measurement of $\mathrm{T}$ specific activity in precipitation in Niigata City, and (2) to investigate the concentrations of cations $\left(\mathrm{Na}^{+}, \mathrm{K}^{+}, \mathrm{Ca}^{2+}\right.$, and $\left.\mathrm{Mg}^{2+}\right)$ in precipitation associated with air mass transport patterns. Data obtained were compared to clarify the relationship between the concentration of major ions and $\mathrm{T}$ specific activity. In addition, we also clarified the activity in precipitation between normal and typhoon events.

In this work, to analyze the low-levels of $\mathrm{T}$ in natural water sample, we used a cryogenic distillation process as the first pretreatment step $^{7-9)}$. After we applied the electrolysis enrichment method (SPE method) ${ }^{6)}{ }^{10), 11)}$, T specific activity of each enriched sample was detected by low-background liquid scintillation counter (LSC). Additionally, backword trajectory analysis has been also conducted to estimate the passing route of air mass which brings about the precipitation ${ }^{12)-14}$.

\section{Experimental}

$2 \cdot 1$ Standards, reagents, and materials

HTO water (its specific activity was $3.7 \times 10^{7}$ $\mathrm{Bq} \cdot \mathrm{cm}^{-3}$ ) purchased from Japan Radioisotope Association was used to determine the $\mathrm{T}$ detection efficiency.

The standard solutions of $\mathrm{Na}^{+}, \mathrm{K}^{+}, \mathrm{Ca}^{2+}$, and $\mathrm{Mg}^{2+}$ were prepared by diluting a $1000 \mathrm{mg}$. $\mathrm{dm}^{-3}$ standard solution, respectively. Respective standard solutions $\left(1000 \mathrm{mg} \cdot \mathrm{dm}^{-3}\right)$ were purchased from KANTO CHEMICAL in Japan. Distilled water was used for the preparation of standard solutions.

In the distillation process, GR grade $\mathrm{Na}_{2} \mathrm{O}_{2}$ was supplied from Wako Pure Chemical and $\mathrm{KMnO}_{4}$ was also from KANTO CHEMICAL. After electrolytic enrichment, $30 \mathrm{~mL}$ of the sample was introduced into a $145 \mathrm{~mL}$ polyethylene scintillation vial provided from ZINSSER ANALYTIC, Germany, with $70 \mathrm{~mL}$ of the liquid scintillation cocktail (ULTIMA GOLD ${ }^{\mathrm{TM}}$ LLT) provided from Perkin Elmer, USA.

\section{$2 \cdot 2$ Apparatus}

$\mathrm{T}$ was precisely determined by an LB5 (Aloka Co., LTD, Japan) liquid scintillation counter.

A Z-5000 Polarized Zeeman (HITACHI, Japan) Atomic Absorption Spectrometer was used for determining the concentrations of $\mathrm{Na}^{+}$, $\mathrm{K}^{+}, \mathrm{Ca}^{2+}$, and $\mathrm{Mg}^{2+}$ in precipitation. The measurements were carried out with flame atomization, and a deuterium lamp was used as background correction. Table 1 illustrates the instrumental operation for each analysis.

\section{$2 \cdot 3$ Samples}

The location of the point for precipitation (Niigata City) is shown in Fig. 1. Each precipitation in Niigata City was sampled. Niigata City has a shoreline on the Sea of Japan and influenced by the monsoon. The sampling site was installed on the rooftop of the faculty of engineering, Niigata University $\left(139^{\circ} 02^{\prime} \mathrm{E}, 37^{\circ} 55^{\prime} \mathrm{N}\right)$. Monthly precipitation consisted of bulk precipitation, the imitative ground infiltrated precipitation, and short term precipitation were obtained from the same site. For short term precipitation, sampling times varied between 1 and several h, depending on each meteorological condi- 
Table 1 Instrumental parameters for the determination of $\mathrm{Na}, \mathrm{K}, \mathrm{Ca}$ and $\mathrm{Mg}$ in each precipitation sample by flame spectrometry and atomic absorption spectrometry

\begin{tabular}{cccc}
\hline Element & $\frac{\lambda}{(\mathrm{nm})}$ & $\underline{\underline{\text { Current }}}$ & Gas \\
& 589.0 & -- & \\
\hline $\mathrm{Na}$ & 766.5 & -- & Air- $_{2} \mathrm{H}_{2}$ \\
$\mathrm{~K}$ & 422.7 & 9.0 & ${\text { Air- } \mathrm{C}_{2} \mathrm{H}_{2}}^{\mathrm{mA}}$ \\
$\mathrm{Ca}$ & 285.2 & 9.0 & Air- $_{2} \mathrm{H}_{2}$ \\
$\mathrm{Mg}$ & & & Air- $\mathrm{C}_{2} \mathrm{H}_{2}$ \\
\hline
\end{tabular}

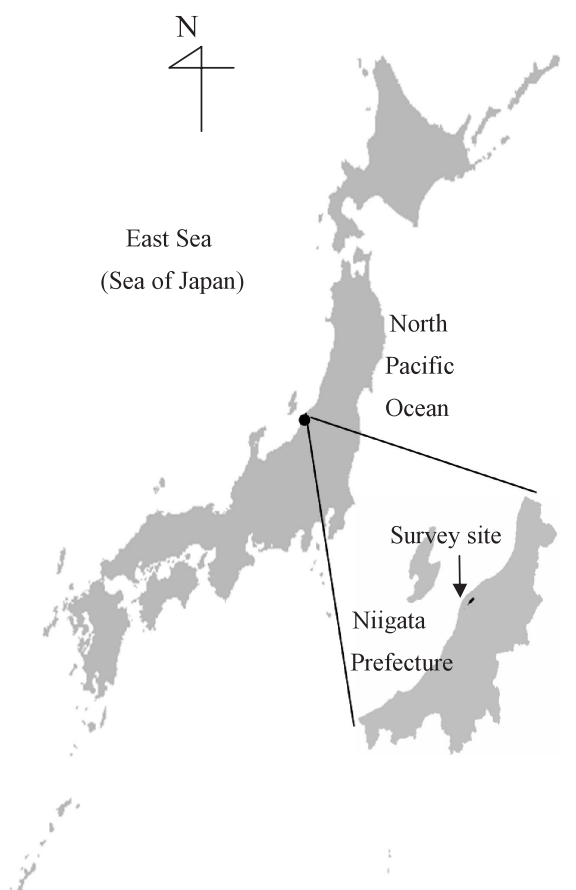

Fig. 1 Location of survey site and Niigata Prefecture.

tion. Most of the samples were collected for $1 \mathrm{~h}$. In this study, several open containers made of plastics were used as collection instrument. Forty one short term samples for chemical analysis were collected from Jun. 2009 to May 2010. During the above-mentioned collecting period short term precipitation samples as three typhoon events were collected: the No.9
Typhoon(Aug. 10, 2009); the No.18 Typhoon (Oct. 8, 2009); and the No.20 Typhoon(Oct. $26-27,2009)$, respectively ${ }^{15)}$.

\subsection{Procedure}

Samples were distilled to remove impurities, to reduce quenching, and to prevent the introduction of other radionuclide which might adulterate the results. Distillation was performed by adding $0.3 \mathrm{~g}$ of $\mathrm{KMnO}_{4}$ and $0.3 \mathrm{~g}$ of $\mathrm{Na}_{2} \mathrm{O}_{2}$ to $1380 \mathrm{~mL}$ of each water sample. Then, the distillated sample was enriched applying SPE (Solid Polymer Electrolysis) method ${ }^{16)}$ before measurement by LSC. Each aliquot of $30 \mathrm{~mL}$ fractions of the enrichment was placed in a $145 \mathrm{~mL}$ polyethylene scintillation vial, and mixed with $70 \mathrm{~mL}$ of ULTIMA GOLD ${ }^{\mathrm{TM}}$ LLT scintillation cocktail.

In addition, the concentrations of $\mathrm{Na}^{+}, \mathrm{K}^{+}$, $\mathrm{Ca}^{2+}$, and $\mathrm{Mg}^{2+}$ in original precipitation were determined by atomic absorption spectrometry and flame photometry.

\subsection{Backward trajectory}

Air mass backward trajectory analysis method provides a useful means of establishing source-receptor relationship of air pollution $^{12), 13)}$. In this study, backward trajectories were computed at integral UTC to cover period $120 \mathrm{~h}$ at height of $1000 \mathrm{~m}$. These detailed 
analysis informations were based on "Meteorological Data explorer ${ }^{17)}$ " by Center for Global Environmental Research, National Institute for Environmental Studies.

\section{Results and discussion}

$3 \cdot 1$ Calculations of $\mathrm{ssCa}^{2+}$ and $\mathrm{nssCa}^{2+}$ in precipitation

The concentrations of major ions in short term precipitation are summarized in Table 2 . Sodium ion is a dominant cation in all samples showing an overall range of 0 to $60.12 \mathrm{mg} \cdot \mathrm{dm}^{-3}$. Moreover, $\mathrm{Na}^{+}$shows higher value during typhoon due to an increase in sea salt aerosols.

In general, the chemical component of precipitation consists of a sea salt (ss) component generated from the ocean and a non sea salt (nss) component derived from the adjacent continents over the seas through long range transport. Here it is assumed that $\mathrm{Na}^{+}$has no source other than marine origin, all other ions originate from both sources.

The concentration of $\mathrm{nssCa}^{2+}$ was calculated from the mass ratio of $\mathrm{Ca}^{2+} / \mathrm{Na}^{+}$in seawater $\left(0.038^{18)}\right)$.

$$
\begin{aligned}
& \operatorname{nss}\left[\mathrm{Ca}^{2+}\right] \\
& =\left[\mathrm{Ca}^{2+}\right]_{\text {total }}-0.038 \times\left[\mathrm{Na}^{+}\right]_{\text {marine }}
\end{aligned}
$$

In this case,

$$
\mathrm{ss}\left[\mathrm{Ca}^{2+}\right]=\left[\mathrm{Ca}^{2+}\right]_{\text {total }}-\mathrm{nss}\left[\mathrm{Ca}^{2+}\right]
$$

$3 \cdot 2$ Long-term or seasonal variations of $\mathrm{T}$ levels in imitative ground infiltrated precipitation

When the precipitation falls on the ground, a small remaining fraction of that (about 10\%) penetrates the soil and infiltrates into the deeper layers of ground by the influence of diffusion, gravity, and capillarity ${ }^{19}$. $\mathrm{T}$ follows the movement of underground water, and its residence time varies according to the characteristics of the movement. Then, in order to obtain $\mathrm{T}$ specific activity in the precipitation, each precipitation was monthly collected with a similar ground infiltration filtrating sampler ${ }^{19)}$ on the rooftop of Niigata University (Fig. 1).

$\mathrm{T}$ specific activities in precipitation samples (imitative ground infiltrated precipitation) taken from Dec. 2003 to Nov. 2009 are plotted in Fig. 2. $\mathrm{T}$ specific activities of imitative ground infiltrated precipitation from Dec. 2003 to Nov. 2006 were also shown in the previous paper $^{16)}$.

As can be seen from Fig. 2, T specific activity in precipitation was found to have a strong dependence on season, and the curves show that the activity has a maximum value in spring and minimum value in autumn and early winter.

An increase of $\mathrm{T}$ in spring is attributed to the downward movement of natural $\mathrm{T}$ from stratosphere to troposphere. As to the northern hemisphere of each year in spring, the warming of the land mass causes an instability in the troposphere between $30^{\circ}$ and $60^{\circ} \mathrm{N}$. This break-up is derived from the mixing of stratospheric air into the troposphere. The stratosphere is the main repository for atmospheric $T$. Since water vapor in the stratosphere cannot exchange directly with water vapor in the ocean, $\mathrm{T}$ specific activity in that reservoir remains higher than that in the troposphere. As a result, there is an increase in $\mathrm{T}$ specific activity in the troposphere of the northern hemisphere, frequently called the "Spring Peak".

The monthly pooled samples of precipitation in Niigata City is a mixture of continents and marine air mass, or at least contains an admixture of a certain percentage of marine vapor in 
Table 2 T specific activity $\left(\mathrm{Bq} \cdot \mathrm{dm}^{-3}\right)$ and several ion concentrations $\left(\mathrm{mg} \cdot \mathrm{dm}^{-3}\right)$ in short term precipitation from Jun. 2009 to May 2010 in Niigata City, Japan

\begin{tabular}{|c|c|c|c|c|c|c|c|c|c|}
\hline Year & Month & Day & Hour & $\mathrm{T}$ & $\mathrm{Ca}^{2+}$ & $\mathrm{Mg}^{2+}$ & $\mathrm{K}^{+}$ & $\mathrm{Na}^{+}$ & $\mathrm{SsCa}^{2+}$ \\
\hline \multirow[t]{40}{*}{2009} & Jun. & 11 & $09: 30 \sim 10: 30$ & 0.900 & 0.008 & 0.043 & 0.150 & 0.190 & 0.007 \\
\hline & & & $10: 30 \sim 11: 30$ & - & 0.108 & 0.034 & 0.141 & 0.002 & 0.000 \\
\hline & & 22 & $16: 30 \sim 17: 30$ & 0.711 & 0.085 & 0.031 & 0.098 & 0.000 & 0.000 \\
\hline & Jul. & 13 & $10: 00 \sim 11: 00$ & 0.735 & 1.141 & 0.598 & 1.089 & 5.050 & 0.192 \\
\hline & & & $11: 00 \sim 12: 00$ & 0.964 & 1.208 & 0.488 & 0.802 & 4.060 & 0.154 \\
\hline & & 17 & $16: 30 \sim 17: 30$ & - & 0.851 & 0.074 & 0.554 & 0.533 & 0.020 \\
\hline & & 18 & $09: 30 \sim 10: 30$ & 0.701 & 0.000 & 0.033 & 0.096 & 0.025 & 0.001 \\
\hline & & & $10: 30 \sim 11: 30$ & 0.644 & 0.012 & 0.033 & 0.098 & 0.013 & 0.000 \\
\hline & & & $11: 30 \sim 12: 30$ & 0.504 & 0.000 & 0.030 & 0.072 & 0.000 & 0.000 \\
\hline & & & $12: 30 \sim 13: 30$ & 0.492 & 0.098 & 0.047 & 0.248 & 0.234 & 0.009 \\
\hline & Aug. & 7 & $08: 30 \sim 09: 30$ & 0.720 & 0.016 & 0.037 & 0.133 & 0.450 & 0.017 \\
\hline & & & $09: 30 \sim 10: 30$ & 0.631 & 0.000 & 0.032 & 0.133 & 0.094 & 0.004 \\
\hline & & & $10: 30 \sim 11: 30$ & 0.644 & 0.000 & 0.036 & 0.110 & 0.410 & 0.016 \\
\hline & & & $11: 30 \sim 12: 30$ & 0.621 & 0.000 & 0.035 & 0.105 & 0.106 & 0.004 \\
\hline & & & $12: 30 \sim 13: 30$ & - & 0.000 & 0.035 & 0.118 & 0.096 & 0.004 \\
\hline & & & $13: 30 \sim 14: 30$ & - & 0.000 & 0.032 & 0.091 & 0.049 & 0.002 \\
\hline & & & $14: 30 \sim 15: 30$ & - & 0.000 & 0.034 & 0.114 & 0.068 & 0.003 \\
\hline & & $10^{*}$ & $08: 30 \sim 09: 30$ & 0.626 & 0.930 & 0.033 & 0.150 & 0.119 & 0.005 \\
\hline & & & $09: 30 \sim 10: 30$ & 0.588 & 0.790 & 0.049 & 0.381 & 0.697 & 0.026 \\
\hline & & & $10: 30 \sim 11: 30$ & - & 0.109 & 0.045 & 0.524 & 0.790 & 0.030 \\
\hline & & & $11: 30 \sim 12: 30$ & - & 0.381 & 0.079 & 1.597 & 1.997 & 0.076 \\
\hline & & & $12: 30 \sim 13: 30$ & - & 0.561 & 0.111 & 1.117 & 1.216 & 0.046 \\
\hline & & & $13: 30 \sim 14: 30$ & - & 0.203 & 0.067 & 0.489 & 0.619 & 0.024 \\
\hline & & & $14: 30 \sim 15: 30$ & - & 0.214 & 0.064 & 0.913 & 0.712 & 0.027 \\
\hline & & & $15: 30 \sim 16: 30$ & - & 0.292 & 0.064 & 1.639 & 1.471 & 0.056 \\
\hline & & & $16: 30 \sim 17: 30$ & 0.610 & 0.064 & 0.038 & 0.476 & 0.523 & 0.020 \\
\hline & & & $17: 30 \sim 18: 30$ & - & 0.133 & 0.048 & 0.718 & 0.817 & 0.031 \\
\hline & Oct. & 2 & $12: 30 \sim 13: 30$ & 0.400 & 0.055 & 0.057 & 0.141 & 0.361 & 0.014 \\
\hline & & & $13: 30 \sim 14: 30$ & 0.344 & 0.000 & 0.032 & 0.063 & 0.017 & 0.001 \\
\hline & & & $14: 30 \sim 15: 30$ & 0.308 & 0.000 & 0.031 & 0.066 & 0.014 & 0.001 \\
\hline & & & $15: 30 \sim 16: 30$ & 0.310 & 0.000 & 0.031 & 0.059 & 0.002 & 0.000 \\
\hline & & & $16: 30 \sim 17: 30$ & 0.303 & 0.000 & 0.033 & 0.097 & 0.040 & 0.002 \\
\hline & & $8^{*}$ & $09: 30 \sim 10: 30$ & 0.305 & 0.530 & 1.580 & 1.600 & 15.380 & 0.584 \\
\hline & & & $10: 30 \sim 11: 30$ & 0.265 & 1.110 & 3.080 & 2.590 & 28.580 & 1.086 \\
\hline & & & $11: 30 \sim 12: 30$ & 0.308 & 3.230 & 7.700 & 5.740 & 60.120 & 2.285 \\
\hline & & & $12: 30 \sim 13: 30$ & 0.373 & 1.600 & 4.590 & 4.170 & 41.180 & 1.565 \\
\hline & & & $13: 30 \sim 14: 30$ & 0.284 & 2.500 & 5.920 & 5.100 & 49.840 & 1.894 \\
\hline & & & $14: 30 \sim 15: 30$ & - & 0.249 & 5.980 & 0.475 & 50.700 & 1.927 \\
\hline & & & $15: 30 \sim 16: 30$ & - & 2.540 & 7.080 & 5.820 & 57.940 & 2.202 \\
\hline & & & $16: 30 \sim 17: 30$ & 0.267 & 2.180 & 6.660 & 5.580 & 55.620 & 2.114 \\
\hline 2010 & May & 27 & $14: 30 \sim 15: 30$ & - & 1.426 & 0.380 & 0.822 & 3.210 & 0.122 \\
\hline
\end{tabular}

“*” These samples were taken during passage of typhoon

"- "represent the defect of date due to small amount of sample 


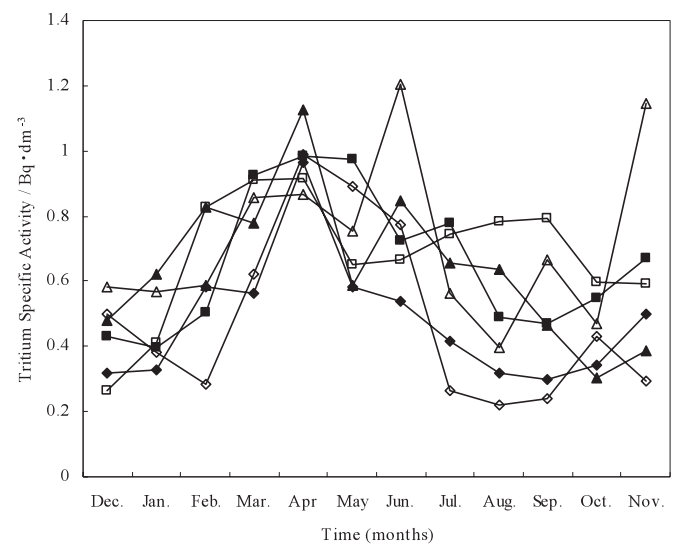

Fig. 2 Annual or seasonal variation of T specific activity in the imitative ground infiltrated precipitation in Niigata City from 2003 to 2009.

: Dec. 03 - Nov. 04, $\square$ : Dec. 04 - Nov. 05

A : Dec. 05 - Nov. 06, $\diamond:$ Dec. 06 - Nov. 07

$\square$ : Dec. 07 - Nov. 08, $\triangle$ : Dec. 08 - Nov. 09

autumn and early winter. The marine air mass crossing Niigata City contains lots of seawater vapor, and decreases $\mathrm{T}$ specific activity in precipitation.

$3 \cdot 3$ Small-scale $\mathrm{T}$ variations in short-term precipitation and backward trajectories

Monthly sampling periods may not capture variations in elemental composition and concentrations due to rapid changes in meteorological conditions (wind speed, wind direction, and temperature, etc.).

Niigata City is influenced by monsoon, and receives a certain amount of compounds from adjacent continent. Thus, Niigata City is a particularly interesting region to study frequent and rapid variation of air mass during one day. $\mathrm{T}$ specific activities and associated ion concentrations of short term precipitation are presented in Table 2.

Comparing normal conditions, large differences in T specific activity have been observed during a typhoon. We collected rain samples

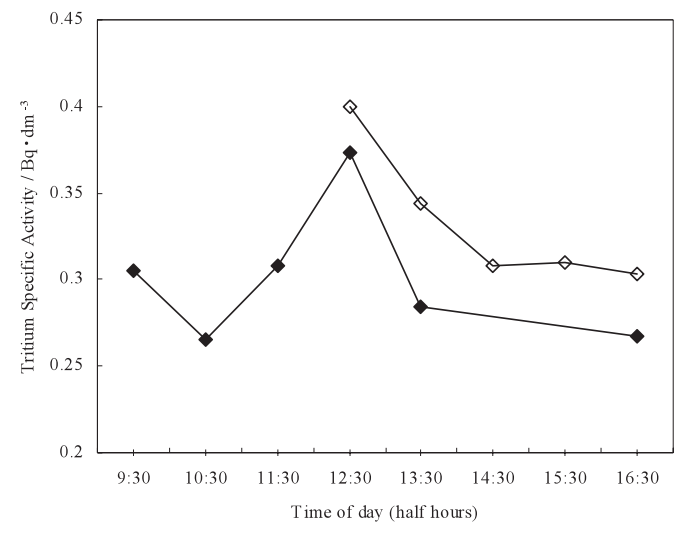

Fig. 3 Relation between the $\mathrm{T}$ specific activity in normal and typhoon precipitation.

$\diamond$ : Normal events (Oct. 2, 2009)

: Typhoon events (Oct. 8, 2009)

during three typhoon events, and also compared $\mathrm{T}$ specific activities in precipitation in normal events with those typhoon events. The results are described in Fig. 3. From this figure, we can observe that $\mathrm{T}$ specific activities in typhoon precipitation are lower than those in normal precipitation. Due to intense weather conditions and violent typhoon winds, large water volumes were carried into the atmosphere. Therefore, some dissolved constituents were diluted with additional freshwater.

Additionally, backward trajectories of normal events and typhoon events are represented in Figs. 4a and 4b. Trajectories were computed hourly for 120 -h periods at an elevation of $1000 \mathrm{~m}$ above ground level.

In order to further clarify the movement and origin of air mass, we compared sequential $\mathrm{T}$ specific activities in typhoon with those in the imitative ground infiltrated precipitation in October. The compared result is given in Fig. 5. A ratio of $\mathrm{nsSCa}^{2+}$ to allCa ${ }^{2+}$ (i.e. $\left[\mathrm{Ca}^{2+}\right]_{\text {total }}$ ) is laid on abscissa. The ratio tending to zero refers to the air mass originated from ocean; on the 
(a)

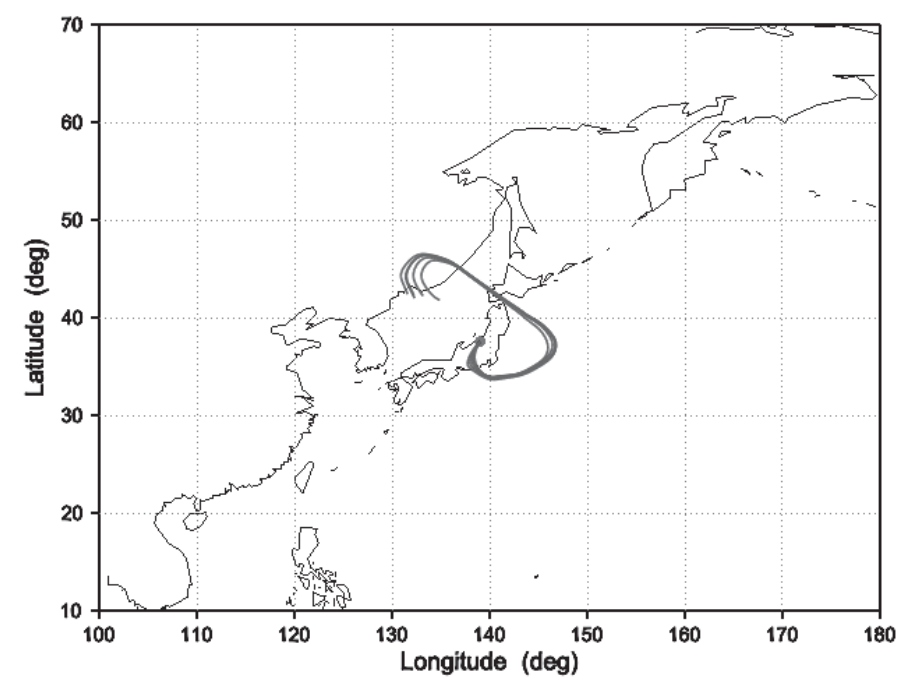

(b)

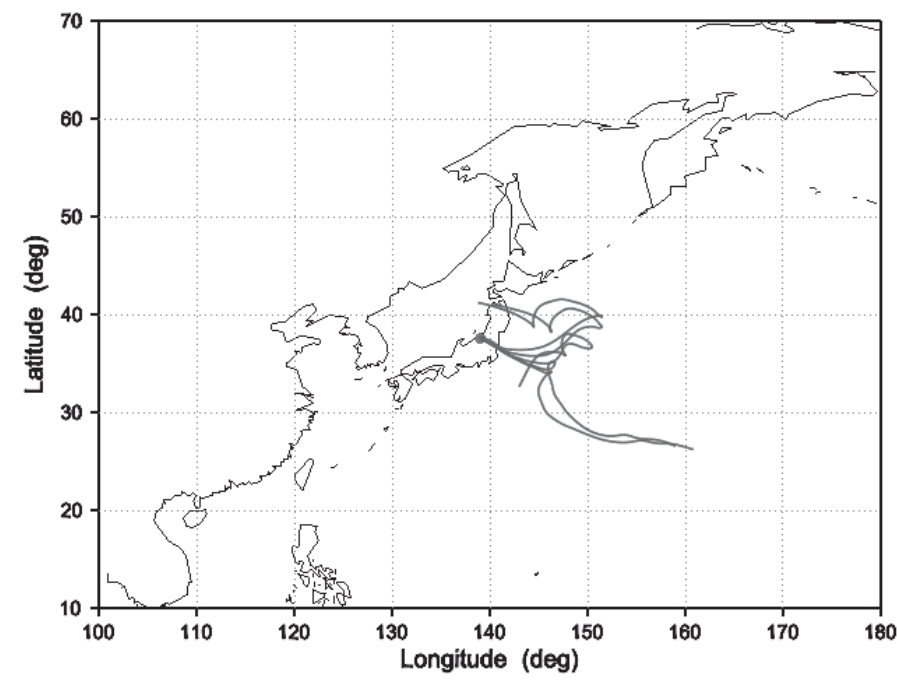

Fig. 4 Clusters of 120 -h backward trajectories with an arriving altitude of $1000 \mathrm{~m}$ at Niigata University $\left(139^{\circ} 02^{\prime} \mathrm{E}\right.$, $\left.37^{\circ} 55^{\prime} \mathrm{N}\right)$.

(a) Oct. 2, 2009 at $4: 00,5: 00,6: 00,7: 00$ and $8: 00$ UTC (Normal events)

(b) Oct. 8, 2009 at $1: 00,2: 00,3: 00,4: 00$ and $5: 00$ UTC (typhoon events)

contrary, the ratio tending to 1 means the air mass was derived from continent. The average of $\mathrm{T}$ specific activity in long term precipitation from 2003 year is $0.449 \mathrm{~Bq} \cdot \mathrm{dm}^{-3}$, and the mean ratio of $\mathrm{nssCa}^{2+}$ to allCa ${ }^{2+}$ is 0.326 . By contrast, parameters in typhoon events were lower than the average $\mathrm{T}$ specific activity and smaller than the mean ratio. It is considered that the precipitation during typhoon has notable character of marine air mass. 


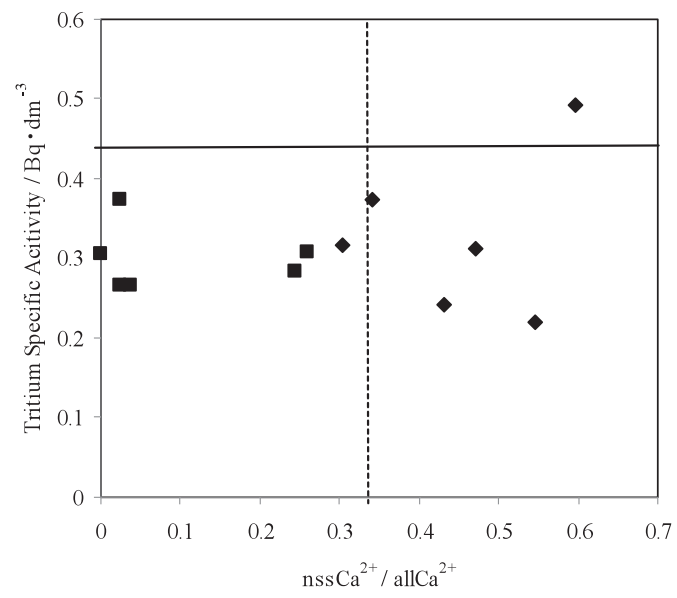

Fig. 5 The ratio of $\mathrm{nssCa}^{2+}$ to $\mathrm{allCa}^{2+}$ in precipitation vs. T specific activity.

口 : precipitation by a typhoon on Oct. 8, 2009

$\checkmark$ : precipitation of imitative ground infiltration in October from 2004 to 2009

Rapid fluctuations in $\mathrm{T}$ can be expected, if, in a short period, different air mass contributes to the precipitation at the site. During this research period, we found that the result of $\mathrm{T}$ in precipitation on Oct. 2, 2009 had notable divergence with that on Oct. 8, 2009 (Table 3). The average value is lower than that in monthly sample in the similar month. The more detail of these are shown in Table 3.

From the theoretical overview, those divergent $\mathrm{T}$ specific activities are related to different origin and movement of air mass. Backward trajectory analysis method was applied to support and corroborate this result. The analytical results are depicted in Figs. 6a and 6b. Figure 6a refers to the trajectory at 4:00 UTC for Oct. 2, 2009. Figure 6b shows backward trajectory representative at 5:00 UTC for Oct. 8, 2009. From those figures, the pass routes of air mass are clearly found. The trajectory of air mass (Oct. 2, 2009) passed through the adjacent continent, i.e., dry continental character of air mass resulted in high $\mathrm{T}$ specific activities in precipitation. On the other hand, the pass route of air mass (Oct. 8, 2009) came from the sea, and marine air mass might affect precipitation character. Therefore, lower $\mathrm{T}$ was obtained as a result. It should be pointed out that combining both experimental results and backward trajectory analysis method provides a useful characterization of the move-

Table 3 T specific activity in hourly and monthly precipitation in October

\begin{tabular}{|c|c|c|c|}
\hline \multirow[t]{2}{*}{ Sample } & \multirow[t]{2}{*}{ Time } & $\mathrm{T}$ & \multirow{2}{*}{$\frac{\text { Average value of T }}{\mathrm{Bq} \cdot \mathrm{dm}^{-3}}$} \\
\hline & & $\mathrm{Bq} \cdot \mathrm{dm}^{-3}$ & \\
\hline Short-term precipitation & Oct. 2, 2009 & & 0.342 \\
\hline \multirow[t]{3}{*}{ in October, 2009} & $12: 30 \sim 13: 30$ & 0.400 & \\
\hline & Oct. 8, 2009 & & \\
\hline & $13: 30 \sim 14: 30$ & 0.284 & \\
\hline Imitative ground infiltrated & 2004 & 0.342 & 0.449 \\
\hline precipitation in October, 2004 & 2005 & 0.547 & \\
\hline \multirow[t]{4}{*}{2009} & 2006 & 0.303 & \\
\hline & 2007 & 0.432 & \\
\hline & 2008 & 0.597 & \\
\hline & 2009 & 0.471 & \\
\hline
\end{tabular}



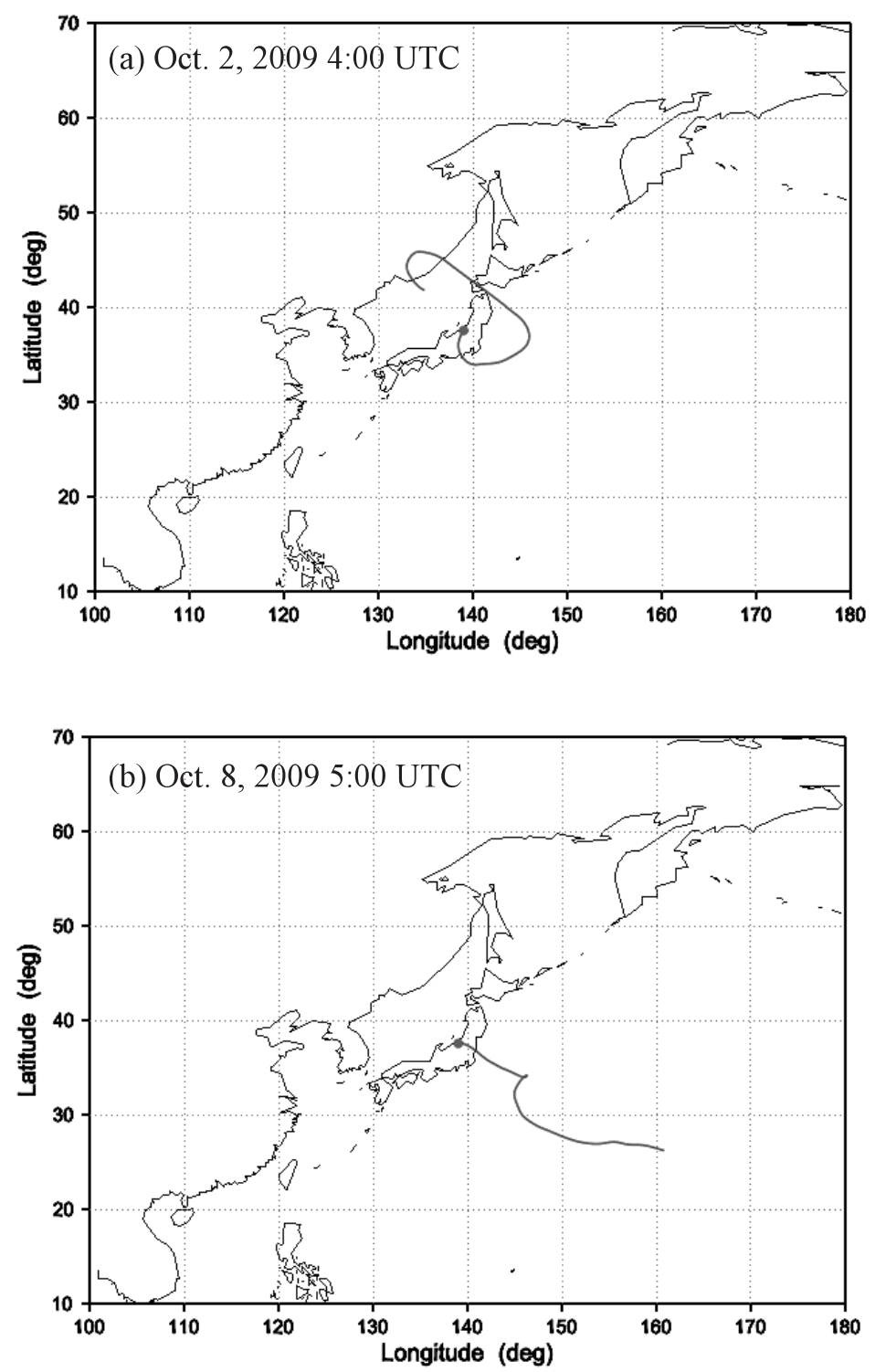

Fig. 6 5-days backward trajectory arrived at Niigata University $\left(139^{\circ} 02^{\prime} \mathrm{E}, 37^{\circ} 55^{\prime} \mathrm{N}\right)$ with $1000 \mathrm{~m}$ altitude.

(a) The initial time is $4: 00$ UTC, Oct. 2, 2009

(b) The initial time is 5:00 UTC, Oct. 8, 2009

ment of air mass.

3.4 Major ionic components in precipitation

Concentrations of ions such as $\mathrm{Na}^{+}, \mathrm{K}^{+}, \mathrm{Ca}^{2+}$, and $\mathrm{Mg}^{2+}$ in imitative ground infiltrated pre- cipitation were measured from Dec. 2003 to Nov. 2009 at the site (Fig. 1). The variations of them depending on time are shown in Figs. $7 \mathrm{a}^{-}$ $\mathrm{d}$, respectively. In these figures, it is found that the seasonal variations of $\mathrm{Ca}^{2+}$ concentration and $\mathrm{T}$ specific activity are very similar: in- 

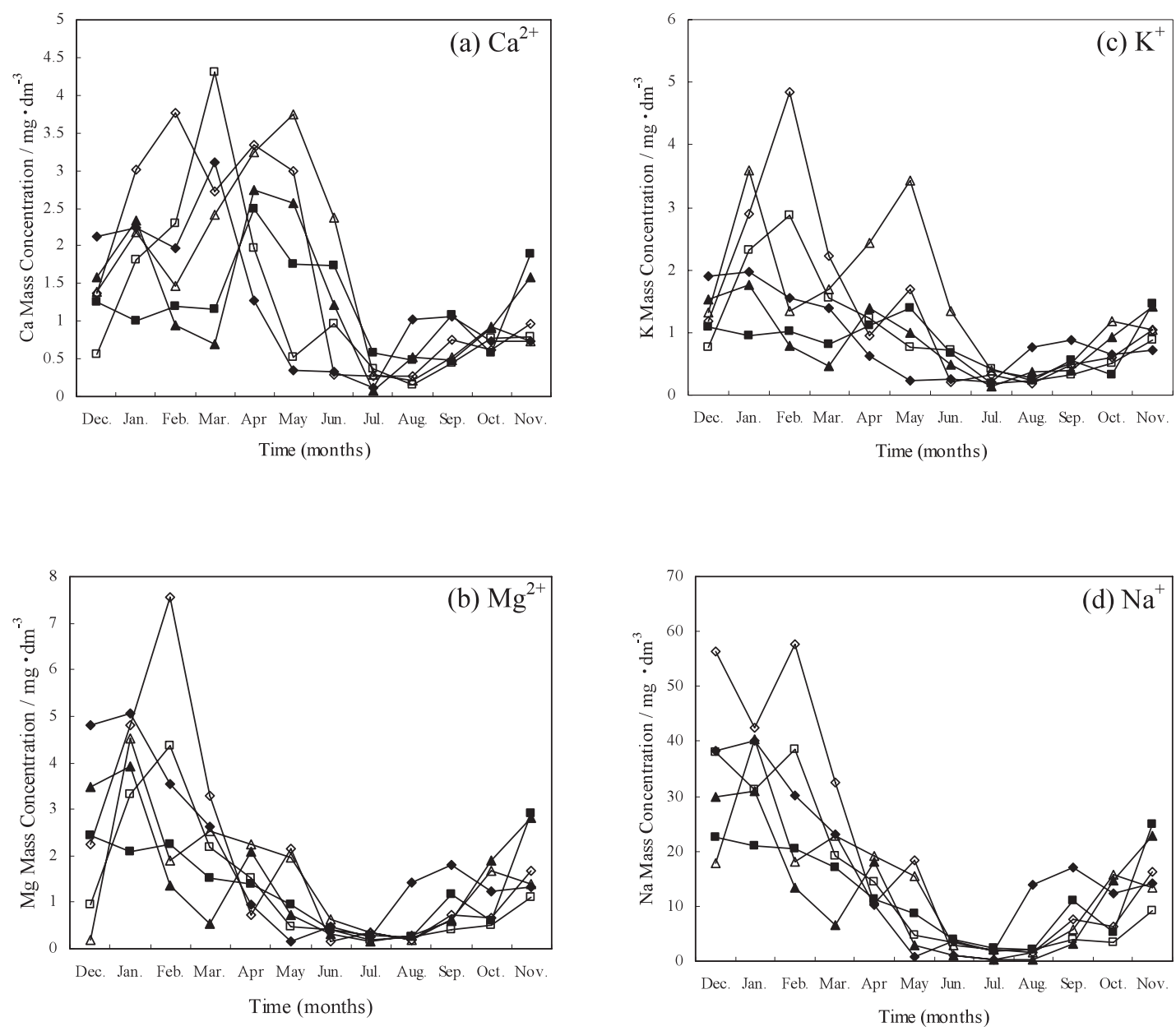

Fig. 7 Time dependence of mass concentration of ions.
:Dec. 03 - Nov. 04, $\square$ :Dec. 04 - Nov. 05
$\boldsymbol{\Delta}$ :Dec. 05 - Nov. 06, $\diamond:$ Dec. $06-$ Nov. 07
$\square$ :Dec. 07 - Nov. 08, $\triangle$ :Dec. 08 - Nov. 09

crease in spring, and decrease between autumn and winter through the year. It seems that using the data of $\mathrm{Ca}^{2+}$, the behavior of $\mathrm{T}$ can be deduced and the movement of precipitation can be also deduced in Niigata region.

\section{Conclusion}

In this study, the following main conclusions have been obtained :

(1) T and associated ions in monthly precipitation showed a seasonal variation; in fact, the seasonal variation of $\mathrm{T}$ specific activity and $\mathrm{Ca}^{2+}$ concentration were very similar. That is, they increase in spring and then decrease from autumn to early winter through the year.

(2) The chemical components in short term precipitation during typhoon have notable character of marine air mass.

(3) Backward trajectory analysis method for air mass provides a useful method to understand the movement of short term precipitation and estimate air pollution. 
Part of this study was presented at the $44^{\text {th }}$ (July 4-6, 2007, Tokyo), 46 $6^{\text {th }}$ (July 1-3, 2009, Tokyo), and $47^{\text {th }}$ (July $7-9,2010$, Tokyo) “Annual Meeting on Radioisotope and Radiation Research”, and at the $9^{\text {th }}$ (Nov. 3, 2010, Tokyo) “Atomic Energy Society of Japan Meeting”.

\section{Acknowledgement}

This work was supported by funds from Fujikura company and Tohoku Houshasen Kagaku Center.

\section{References}

1) Lucas, L. L. and Unterweger, M. P., J. Res. Nat. Inst. Stand. Technol., 105, 541-549 (2000)

2) Villa, M. and Manjón, G., Appl. Radiat. Isot., 61, 319-323 (2004)

3) Palomo, M., Peñalver, A., Aquilar, C. and Borrull, F., Appl. Radiat. Isot., 65, 1048-1056 (2007)

4) Belot, Y., Roy, M. and Métivier, H., IPSN (1996)

5) Pradeep, K. A., Joel, R. K. and Klaus, F.O.F., Isotopes in the Water Cycle : Past, Present and Future of a Developing Science, pp.53-63, Springer, Austria (2005)

6) Wolfango, P., Iosif, C., Stela, C., Lauri, K., Pierino, D. F., Nicolae, L., Gabriela, B., Valentin, M., Petre, B. and Calin, B., Radiat. Meas., 42, 68-73(2007)

7) Hisamatsu, S., Takizawa, Y., Itoh, M., Ueno, K. and Katsumata, T., Health Phys., 57, 559-563(1989)

8) Fukada, S., Fujiwara, H., J. Chromatogr., A., 898, 125-131 (2000)

9) Baeza, A., Díaz, M., García, E. and Mirò, C., J. Radioanal. Nucl. Chem., 252, 441-449 (2002)

10) Sauzay, G. and Schell, W. R., Int. J. Appl. Radiat. Isot., 23, 25-33 (1972)

11) Grigoriev, S. A., Millet, P., Korobtsev, S. V., Porembskiy, V. I., Pepic, M., Etievant, C., Puyenchet, C. and Fateev, V. N., Int. J. Hydrogen Energy, 34, 5986-5991 (2009)

12) Stohl, A., Atmos. Environ., 32, 947-966 (1998)

13) Beverland, I. J., Tunes, T., Sozanska, M., Elton, R. A., Agius, R. M. and Heal, M. R., Int. J. Environ. Health Res., 10, 229-238 (2000)

14) Zeng, J., Matsunaga, T. and Mukai, H., Environmental Modelling \& Software, 25, 607-608 (2010)

15) Japan Meteorological Agency:Information for typhoon, http : //www.data.jma.go.jp/fcd/yoho/ typhoon/index.html

16) Takahashi, Y., Imaizumi, H., Kano, N., Saito, M., Kato, N., Ishii, Y., and Saito, K., RADIOISOTOPES, 57, 375-383 (2008)

17) Center for Global Environmental Research, National Institute for Environmental Studies: Meteorological Data Explorer, http://db.cger.nies. go.jp/metex/index.jp.html

18) Nakamura, T., Matsumoto, K. and Uematsu, M., Atmos. Environ., 39, 1749-1758 (2005)

19) Murphy, C. E., Health Phys., 65, 683-697 (1993) 
要旨

\title{
トリチウムをトレーサとした降水の挙動
}

焦 玉栄, 石田さゆり, 高田佳代子*, 今泉 洋*, 狩野直樹*, 斎藤正明**

\author{
新潟大学大学院自然科学研究科 \\ $*$ 新潟大学工学部化学システム工学科 \\ 950-2181 新潟県新潟市西区五十嵐二の町 8050 \\ **東京都立産業技術研究センター \\ 158-0081＼cjkstart東京都世田谷区深沢 2-11-1
}

水文学において, トレーサ技術は気団動態や污染物質の輸送に関して最も効果的な方法の一つで ある。このトレーサ技術を用いて気団動態を観測するため，新潟市において，降水中のトリチウム の現地調査を行った。この試料水 (降水) を蒸留・電解濃縮後, 液体シンチレーションカウンタで トリチウム放射能を測定した。更に, その場所に到達した気団動態のパターンと結びつけるため, 降水中の陽イオン $\left(\mathrm{Na}^{+}, \mathrm{K}^{+}, \mathrm{Ca}^{2+}, \mathrm{Mg}^{2+}\right)$ 濃度も測定した。以上から，次のことが明らかにな った。

（1）降水中のトリチウム放射能は，採水場所や季節に強く依存する。

（2）台風による降水中の化学組成は, 海洋性気団の特徴が強く見られる。

（3）月間降水中のイオンは季節的変動が見られ, カルシウムイオン濃度とトリチウム放射能の季節 的変動とはよく類似している。

（4）後方流跡線解析法は, 短期降水中の $\mathrm{T}$ 放射能や各種イオンの動態を解析するのに有用である。 